\title{
Australian Journal of

\section{Effect of sowing time on the growth and yield of sweet corn (Zea mays L.) cultivated during fall-winter period in Subtropical climate}

\author{
Antônio Augusto Nogueira Franco*1, Pedro Soares Vidigal Filho ${ }^{1}$, Carlos Alberto Scapim ${ }^{1}$, Ricardo \\ Shigueru Okumura ${ }^{2}$, Odair José Marques ${ }^{3}$, Alberto Yuji Numoto ${ }^{1}$ \\ ${ }^{1}$ Universidade Estadual de Maringá, Maringá, State of Paraná, Brazil \\ ${ }^{2}$ Universidade Federal Rural da Amazônia, Parauapebas, State of Pará, Brazil \\ ${ }^{3}$ Universidade Federal de Uberlândia, Monte Carmelo, State of Minas Gerais, Brazil
}

*Corresponding author: antonioaugustonf@yahoo.com.br

\begin{abstract}
The aims of the study were to investigate the effect of sowing time on the phenotypic response of sweet corn hybrids cultivated during the fall-winter period, with supplementary irrigation, in Northwest Region of Paraná State, where has a Subtropical climate, without a specific dry season. The treatments consisted of the combination of four sowing dates $(02 / 18 ; 03 / 04 ; 03 / 18 ; 04 / 01)$ and two commercial sweet corn hybrids (Tropical Plus and RB6324) in two years (2011 and 2012). The characteristics assessed were growth, production component, phenological cycle and accumulated thermal sum. The sweet corn plant growth was limited by delay in the sowing time that negatively affected the production components. The postponement of sowing time did not influence the accumulated thermal sum, although the number of days to harvest of the plants sown on February $18^{\text {th }}$ and April $4^{\text {th }}$ were, respectively, 93 and 120 days. The hybrid RB6324 presented the best productive performance and the second half of February was the preferential time for sowing sweet corn in the fall-winter period in the Northwest Region of Paraná State, Brazil.
\end{abstract}

Keywords: climatic factors, physiology, second crop, special corn.

Abbreviations: LAI_leaf area index, RUE_radiation use efficiency, $\mathrm{R}_{1 \_}$silking, $\mathrm{R}_{2}$ blister grain, $\mathrm{R}_{3 \_}$milky grain, $\mathrm{ST}$ _sowing time(s), VT_tasseling.

\section{Introduction}

The corn grown in the fall-winter period, also known as second season corn is sown after a summer crop, that is, at the end of the recommended period (Forsthofer et al., 2006; Sangoi et al., 2007). The system of second season corn production has been perfected and has contributed to raise the yields of the crops grown in this period (Cruz et al., 2010), although carried out under less favorable climatic conditions. The success of this cultivation mode is due to the fact that common corn has always been the target of scientific research (Embrapa, 2012), unlike that observed for the corns considered as special, such as sweet corn, so producers use recommendations suggested for common corn, those are not always ideal (Martin and Williams, 2008). The main characteristic of sweet corn is that it has genes whose expression alters the grain composition (Creech, 1965). These genes block the conversion of sugars to starch in the endosperm resulting in the accumulation of high sugar content in the grains in detriment of the starch (Boyer and Shannon, 1984). This characteristic adds value to the product, which has been gaining space and demand is growing in Brazil (Barbieri et al., 2005). However, there is little information for proper sweet corn management, because the agronomic practices for this crop differ greatly from those recommended for common corn, including scheduled planting, shorter time interval to harvest and shorter grain filling period (Martin and Williams, 2008). Thus, the time that the crop is exposed to climatic factors is different from grain corn and it is known that the Zea mays L. species is strongly influenced by environmental factors (Tollenaar, 1999; Tsimba et al., 2013a, b). On the other hand, temperature, solar radiation, photoperiod and rainfall vary randomly around seasonal average tendencies, so that the greatest challenge is adjusting the ideal time for sowing (Tsimba et al., 2013a). The proper positioning of the sowing time (ST) becomes even more challenging because of the climatic change (Laux et al., 2010; Folberth et al., 2012; Liu et al., 2012), those are more rigorous in less developed countries and tropical regions (IPCC, 2013), especially for the corn crop because it is very vulnerable to climatic change (Streck et al., 2012). Waha et al. (2013a) studied in SubSahara Africa $\left(40^{\circ} \mathrm{N}\right.$ to $40^{\circ} \mathrm{S}$ and $20^{\circ} \mathrm{W}$ to $\left.60^{\circ} \mathrm{E}\right)$, founded that the regions are much more influenced where the second season is grown (sowing in the second half of the wet season). In this context, the proper ST acquires immense importance, so that the fields avoid negative climatic conditions (Laux et al., 2010; Liu et al., 2013; Tsimba et al., 2013a; Waha et al., 2013b) without overloading production cost (Sangoi et al., 2006). The potential sweet corn yield can be maximized by choosing the proper ST (Martin and Williams, 2008; Khan et al., 2011). Furthermore, producers can reduce the negative impact of possible climatic change, adapting the ST to the new climatic scenarios (Waha et al., 2013b). Studies carried out in Cameroons indicated that the yields of corn and peanut crops sown in current times are normally higher than those obtained using older ST (Laux et al., 2010). This fact corroborates with Waha et al. (2013b), 
who reported the adjustment the ST resulted in greater yield in Sub-Sahara Africa.

Martin and Williams (2008) studied the influence of ST on the agronomic characteristics of sweet corn hybrids and founded that the plants grew $13 \%$ to $23 \%$ more than the used by the producers in the Central Northern Region of the United States. The authors emphasized that few studies have characterized sweet corn growth and yield in response to environmental conditions resulting from the change in a range of ST used by the producers. They pointed out that if responses of sweet corn growth varied systematically with the ST, an in-depth knowledge of the phenomenon can lead to new opportunities to advance management of the crop.

In this context, the present study is justified by the referred lack of knowledge, because of the importance of Paraná in the Brazilian agricultural scenario and climatic change. Therefore, the aims of this study were to assess the effect of ST on the agronomic characteristics of two sweet corn hybrids, sown in the fall-winter period, in Northwestern Paraná State, Brazil.

\section{Results and Discussion}

\section{Climatic characteristics}

In 2011, the bulk of rainfall was concentrated mainly in March, April and July and the total rainfall during the cultivation period was $273 \mathrm{~mm}\left(\mathrm{ST}_{1}\right) ; 329 \mathrm{~mm}\left(\mathrm{ST}_{2}\right) ; 353$ $\mathrm{mm}\left(\mathrm{ST}_{3}\right)$ and $393 \mathrm{~mm}\left(\mathrm{ST}_{4}\right)$ (Fig. 1). In 2012, the rainfall was more regular in June and July and in the same sequence, the total rainfall during the cultivation period was $261 ; 293$; 509 and $495 \mathrm{~mm}$ (Fig. 1).

These rainfall volumes are considered insufficient for the water requirement of the corn crop because the rainfall was below the lower limit of $500 \mathrm{~mm}$ (Silva et al., 2010), except for the plants sown on the third time of agricultural year in 2012 (Fig. 1). Thus, in both years, supplementary irrigation was very relevant to replace the daily evapotranspiration of plants (Resende and Oliveira, 2005).

Delay of ST (e.g. $\mathrm{ST}_{3}, \mathrm{ST}_{4}$ ) in Autumn-Winter period of year 2011 and 2012 coincided with a reduction of temperature (Fig. 1). The average maximum and minimum temperatures were: 29.8 and $14.6^{\circ} \mathrm{C}\left(\mathrm{ST}_{1}\right) ; 28.7$ and $13.3^{\circ} \mathrm{C}$ $\left(\mathrm{ST}_{2}\right) ; 28.3$ and $11.3{ }^{\circ} \mathrm{C}\left(\mathrm{ST}_{3}\right) ; 28.2$ and $10.8{ }^{\circ} \mathrm{C}\left(\mathrm{ST}_{4}\right)$, for 2011 and 31.0 and $14.3{ }^{\circ} \mathrm{C}\left(\mathrm{ST}_{1}\right), 29.7$ and $13.2{ }^{\circ} \mathrm{C}\left(\mathrm{ST}_{2}\right)$, 28.6 and $11.6{ }^{\circ} \mathrm{C}\left(\mathrm{ST}_{3}\right), 27.5$ and $10.8{ }^{\circ} \mathrm{C}\left(\mathrm{ST}_{4}\right)$, for 2012 (Fig. 1C). In 2011, more precisely, on June 28 there was a frost, affecting the plants sown on seasons $3(03 / 18)$ and $4(04 / 1)$, where they were at stages $R_{2}$ and $V_{T}$, respectively (Fig. 1). Although the frost damage was not assessed, considerable necrosis was observed on the leaf of the mid-third and upper of the plants, affecting drastically plant leaf area. In 2011, LAI of the plants sown on 03/18 (2.57) and 04/01 (1.83) was significantly lower than those observed in 2012 agricultural year; $2.94(03 / 18)$ and 2.77 (04/01) (Table 4).

Temperatures that induce frost have on the protoplasm of the plant the same effect desiccation, leading to dehydration of the tissue (loss of cell turgidity) due to decrease in the hydraulic conductance - low amount of aquaporins (Aroca et al., 2012) and less stomatal control (Steudle, 2000). The lipid layer is destroyed, the membrane proteins are disassociated and the ATPase activity decreases (Larcher, 2000), with plasmatic membrane rupture and extravasation of cellular contents, which is necrosis (Guy, 1990).

For these reasons, to avoid further losses, on June 28 of 2011 , water was applied by irrigation between 04:30 to 08:00 a.m. The application of water under these circumstances favours tissue hydration and promotes the thawing of solidified dew on the aerial parts of the plants, contributing to raising the temperature (Larcher, 2000). In 2012, it was observed larger quantities of solar radiation (Fig. 1). Regarding the photoperiod, similar to temperature and solar radiation, it was found very pronounced reductions with displacement of sowing time from February to March (Fig. 1B). In February was observed the maximum number of sunshine $(12.65 \mathrm{~h})$ and the minimum was observed at the end of June $(10.56 \mathrm{~h})$ (Fig. 1).

\section{Phenological cycle and accumulated thermal sum}

The phenological cycles studied of sweet corn hybrids are similar and the lags of sowing increased them (Fig. 2). In 2011 , the number of days, the average of hybrids, between sowing $-\mathrm{V}_{\mathrm{T}}$; and between $\mathrm{V}_{\mathrm{T}}-\mathrm{R}_{3}$ were 62 and 31,68 and 33,76 and 39,84 and 38 , respectively on ST 1, 2, 3 and 4. In the same sequence, in 2012, the number of days were 59 and 33, 66 and 32, 72 and 32, 79 and 37 (Fig. 2). So in the first year, the prolongation of cycle was more pronounced in all ST, overcoming 2012 at $1,3,11$ and 7 days, respectively (Fig. 2). It is important to point out the agricultural year 2011 was colder than 2012, including occurrence of frost (Fig. 1). It is appropriate to highlight another finding that acquires significant meaning, the more restrictive were the environmental conditions of fall-winter, was observed an increase in the number of days between $V_{T}$ and $R_{1}$. In 2011, the duration in days of the said step was $2,3,6$ and 7; versus $2,3,3$ and 5 days in 2012, in the respective sowings in $02 / 18$; 03/04; 03/18 and 04/01 (Fig. 2A). This result may cause asynchrony between $V_{T}$ and $R_{1}$, limiting pollination, with fewer pollinated ovules in the ear and reduction in the final number of kernels.

Guei and Wasson (1992) reported that the male and female flowering dates and the anthesis to $R_{1}$ interval are influenced by water stress, temperature and nitrogen. According to Borrás et al. (2007), environmental conditions that alter plant growth also affect the temporal separation of $V_{T}$ and $R_{1}$, especially female flowering. Reduction of plant growth reduces the accumulation of biomass in the ear in detriment to the tassel, and thus the delay in $\mathrm{R}_{1}$ is interpreted as a consequence of the reduction of biomass allocated to the ears (Pagano and Maddonni, 2007). This asynchrony negatively affects yield because the number of kernels is a function of the rate of accumulation of biomass on the ear around the flowering (Echarte et al., 2004). In addition, delaying the female flowering can induce serious consequences in pollination because when the silks are ready to receive the pollen grains, most of them, are no longer viable, with strong reductions in the final number of kernels (Zinselmeier et al., 1995).

The delay in ST, different from the number of days, did not provide variation in the accumulation of degree days by hybrids (Fig. 2A). The average accumulated thermal sum in the period from sowing to $V_{T}$ and between $V_{T}$ to $R_{3}$ were 850 and 270, 847 and 273 degree days, in 2011 and in 2012, respectively (Fig. 2B). Martin and Williams (2008) investigated different ST in the sweet corn crop observed that the number of days between emergence and $R_{1}$ varied with the times of planting, different to the thermal sum that little has changed. This fact is explained because corn requires an accumulation of degree days to complete the development stages and only then move on to another stage (Tsimba et al., 2013b). On the other hand, the thermal unit is directly proportional the temperature (Cross and Zuber, 1972; Gaile, 2012). Then, at low temperatures the daily thermal units are 
Table 1. Chemical analyses of soil material from experimental plots from layers $0-0.20$ and $0.20-0.40 \mathrm{~m}$ of depth, in the fallwinter period of 2011 and 2012 agricultural years.

\begin{tabular}{|c|c|c|c|c|c|c|c|c|c|c|}
\hline \multirow{3}{*}{ Years } & $\mathrm{pH}$ & $\mathrm{C}$ & $* \mathrm{P}$ & $* \mathrm{~K}^{+}$ & $* * \mathrm{Ca}^{+2}$ & $* * \mathrm{Mg}^{+2}$ & $* * \mathrm{Al}^{+3}$ & SB & CTC & $\mathrm{V}$ \\
\hline & $\mathrm{CaCl}_{2}$ & $\mathrm{~g} \mathrm{dm}^{-3}$ & $\mathrm{mg} \mathrm{dm}^{-3}$ & & ------ & cmc & $\mathrm{n}^{-3}-\cdots$ & 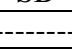 & -- & $\%$ \\
\hline & \multicolumn{10}{|c|}{ Layers $0.00-0.20 \mathrm{~m}$} \\
\hline 2011 & 5.63 & 13.87 & 9.67 & 0.88 & 4.32 & 2.17 & 0,00 & 7.37 & 12.15 & 60.66 \\
\hline \multirow[t]{2}{*}{2012} & 5.20 & 11.74 & 23.30 & 0.35 & 3.75 & 1.50 & 0,00 & 5.60 & 9.88 & 56.68 \\
\hline & \multicolumn{10}{|c|}{ Layers $0.20-0.40 \mathrm{~m}$} \\
\hline 2011 & --- & --- & --- & --- & --- & --- & --- & --- & --- & --- \\
\hline 2012 & 5.20 & 12.52 & 19.50 & 0.32 & 3.80 & 1.40 & 0.00 & 5.52 & 9.49 & 58.17 \\
\hline
\end{tabular}

*Mehlich $1 ; * * \mathrm{KCl} 1 \mathrm{~mol} \mathrm{~L}^{-1}$.
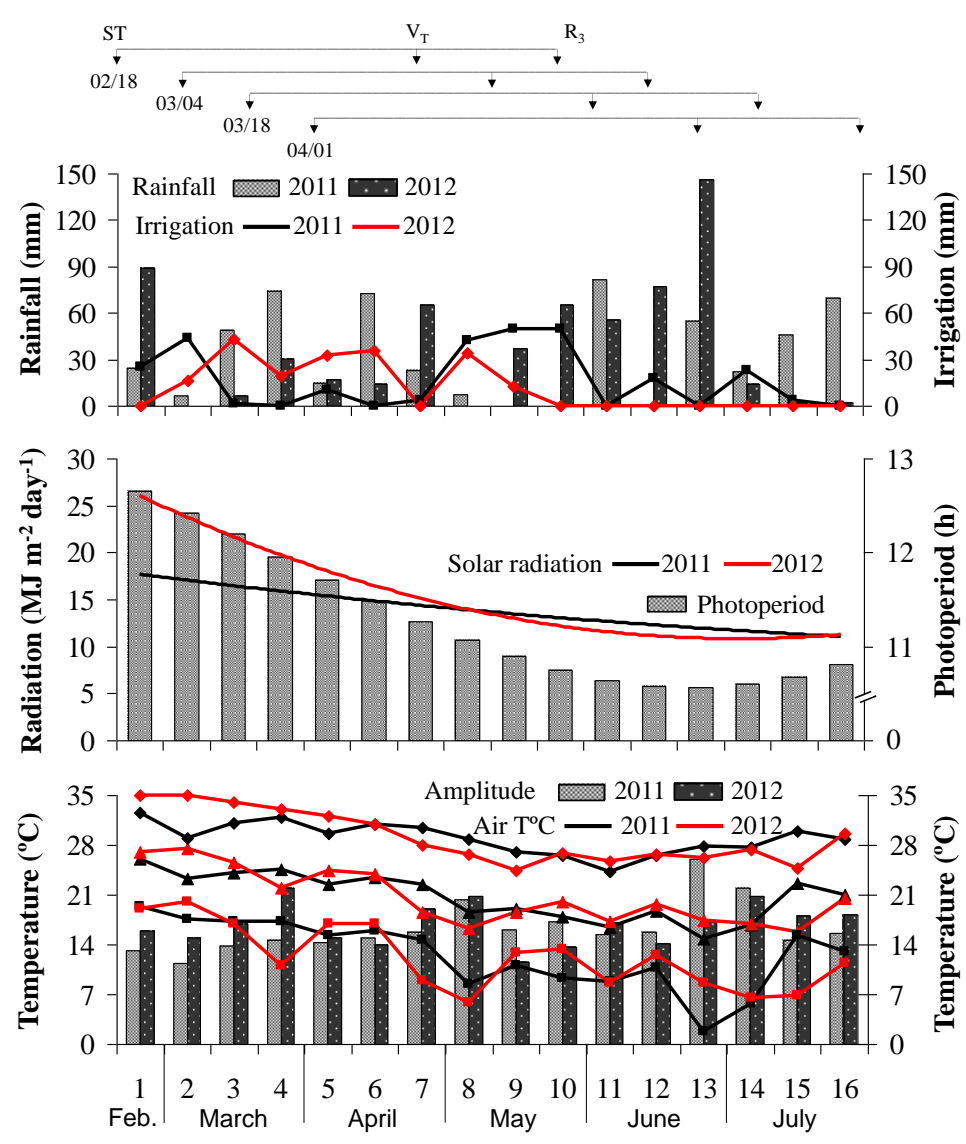

Periods of ten days after sowing

Fig 1. Rainfall and supplemental irrigation (A), solar radiation and photoperiod (B), maximum, minimum average air temperature (Air $\mathrm{T}^{\circ} \mathrm{C}$ ) and thermal amplitude (C) in the fall-winter period of 2011 and 2012, in Maringá, Northwest of Paraná State, Brazil.

smaller, justifying the extension of the phenological phases to complete the required thermal sum accumulation (Bergamaschi et al., 2006). Therefore, thermal time describes the development rate more precisely than the time expressed in days (Soler et al., 2005). The analysis of variance for the main factors, tested in isolation, showed that times factor was significant $(\mathrm{P} \leq 0.05)$ for all studied characteristics (Table 2). The hybrid factor was significant for yield of marketable ear and the agricultural year factor was not significant $(\mathrm{P} \leq 0.05)$ for the number of kernel per row (Table 2). Regarding the interactions, the analysis showed dependence $(\mathrm{P} \leq 0.05)$ between the factors of interaction times $\mathrm{x}$ hybrids to the characteristic number of kernel per row (Table 2). However, for interaction times $\mathrm{x}$ years, was not observed dependence $(\mathrm{P} \geq 0.05)$ between the factors only for the characteristic number of kernel row per ear (Table 2). Finally, the analysis was significant $(\mathrm{P} \leq 0.05)$ for the interaction of hybrids $\mathrm{x}$ years and times $\mathrm{x}$ hybrids $\mathrm{x}$ years only for yield of marketable ear (Table 2)

\section{Growth and plant development characteristics}

The triple interaction (times $\mathrm{x}$ hybrids $\mathrm{x}$ years) for plant height, showed independence $(\mathrm{P} \geq 0.05)$ among the factors, different from that observed for the double interaction times $\mathrm{x}$ years $(\mathrm{P} \leq 0.05)$ (Table 2). However, your partitioning (times $x$ hybrids $x$ years) beyond of significantly adjust $(P \leq 0.05)$, revealed more information than the double interaction in question (Fig. 3). For these reasons, in this specific case was used the results of triple interaction, disregarding the hybrids average, as suggested by Perecin and Cargnelutti Filho (2008) and Barbin (2013). The quadratic polynomial model was that better adjusted to plant height characteristics for the hybrid RB6324 (2011 and 2012) and for the hybrid Tropical Plus in 2011. The maximum heights of the plants were 1.71; 
Table 2. Summary of the variance analysis of sweet corn phenotypic characteristics (plant height - PH, leaf area index - LAI, number of kernel per row - NKR, number of kernel row per ear - NRE, and yield of marketable ear - YIELD) in the fall-winter period of 2011 and 2012, in Maringá city, Northwest Region of Paraná State, Brazil.

\begin{tabular}{|c|c|c|c|c|c|c|}
\hline \multirow{2}{*}{ Font of variations } & \multirow{2}{*}{ DF } & \multicolumn{5}{|c|}{ Mean square } \\
\hline & & $\mathrm{PH}$ & LAI & NRE & NKR & YIELD \\
\hline Times (T) & 3 & $0.411 *$ & $2.515^{*}$ & $4.943^{*}$ & $898.397 *$ & $226.010 *$ \\
\hline Hybrids $(\mathrm{H})$ & 1 & $0.012^{\mathrm{ns}}$ & $0.039^{\mathrm{ns}}$ & $0.303^{\mathrm{ns}}$ & $0.226^{\mathrm{ns}}$ & $2.344 *$ \\
\hline Years (Y) & 1 & $2.303^{*}$ & $10.668 *$ & $3.240 *$ & $1.891^{\mathrm{ns}}$ & $63.421 *$ \\
\hline $\mathrm{T} \times \mathrm{H}$ & 3 & $0.001^{\mathrm{ns}}$ & $0.037^{\mathrm{ns}}$ & $1.129^{\mathrm{ns}}$ & $22.697 *$ & $0.105^{\mathrm{ns}}$ \\
\hline $\mathrm{T} \times \mathrm{Y}$ & 3 & $0.117 *$ & $0.554 *$ & $0.170^{\mathrm{ns}}$ & $50.372 *$ & $6.858 *$ \\
\hline $\mathrm{H} \times \mathrm{Y}$ & 1 & $0.007^{\mathrm{ns}}$ & $0.007^{\mathrm{ns}}$ & $0.063^{\mathrm{ns}}$ & $0.051^{\mathrm{ns}}$ & $3.137 *$ \\
\hline $\mathrm{T} \times \mathrm{H} \times \mathrm{Y}$ & 3 & $0.007^{\mathrm{ns}}$ & $0.009^{\mathrm{ns}}$ & $0.236^{\mathrm{ns}}$ & $8.446^{\mathrm{ns}}$ & $1.475^{*}$ \\
\hline Blocks/Years & 6 & 0.014 & 0.070 & 1.365 & 9.362 & 0.329 \\
\hline Residue & 42 & 0.006 & 0.057 & 0.455 & 4.243 & 0.276 \\
\hline General average & & 1.77 & 2.82 & 15.30 & 33.41 & 6.28 \\
\hline $\mathrm{CV}(\%)$ & & 4.20 & 8.44 & 4.41 & 6.17 & 8.36 \\
\hline
\end{tabular}

*Significat and ${ }^{\mathrm{ns}}$ no significat, in $5 \%$ probability level, by $\mathrm{F}$ test.
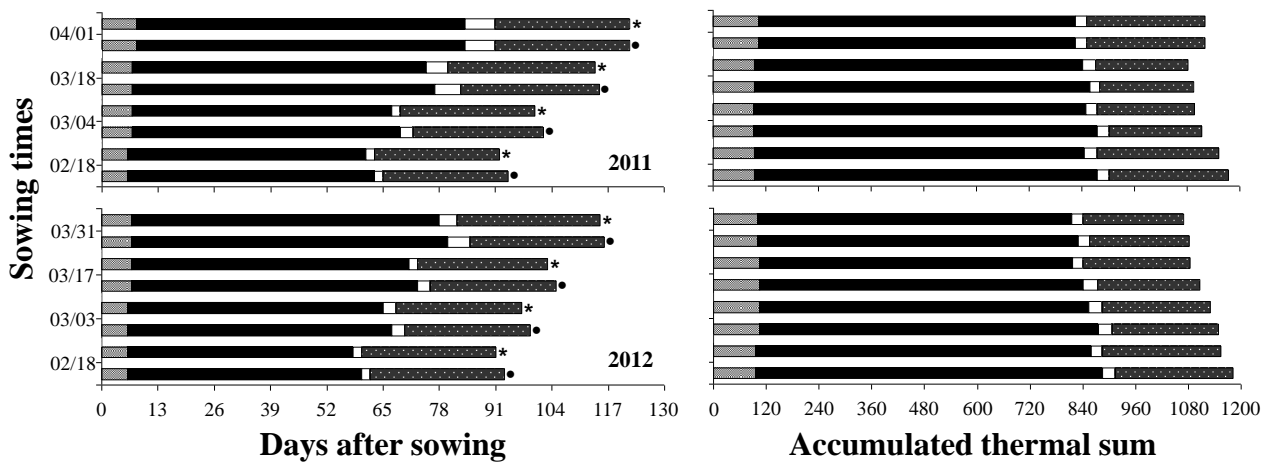

圆 $\square \mathrm{V}_{\mathrm{T}} \square \mathrm{R}_{1} \bullet \mathrm{R}_{3} \bullet$ Tropical Plus $\star \mathrm{RB} 6324$

Fig 2. Days after sowing and accumulated thermal sum till emergence (VE), tasseling $\left(V_{T}\right)$, silking $\left(R_{1}\right)$ and milky grain $\left(R_{3}\right)$ for two sweet corn hybrids, in the fall-winter period of 2011 (A) and 2012 (B), in Maringá, Northwest of Paraná State, Brazil.

2.16 and $1.74 \mathrm{~m}$ in the respective julian days 67 (03/08/2011), $53(02 / 22 / 2012)$ and $67(03 / 08 / 2011)$. For hybrid Tropical Plus in 2012, was adjusted the linear model, with a decrease estimated by the angular coefficient of 1.15 $\mathrm{cm}$ for each day of delay in ST (Fig. 3). In Table 3, it can be seen that the studied hybrids showed very similar plant height, not statistically different $(\mathrm{P} \leq 0.05)$ within times and agricultural years. This result can be explained by the genetic characteristics of hybrids, which present similar development cycle and requirement of thermal sum. Moreover, the simple hybrid has the characteristic be obtained from crossing two endogamic lines that have high uniformity genetic, morphological and phenological (Costa et al., 2010). However, while plant height is a more dependent of genetic factor than environmental factor, there was statistical differences in agricultural years $(\mathrm{P} \leq 0.05)$. The year 2012 overcame 2011, providing more favorable climatic conditions for plant growth in all times (Table 3). Leaf area index (LAI) of sweet corn plants varied with the times and years showing different performances on the average of hybrids. In 2011, the best adjustment was obtained with quadratic regression and the maximum LAI (2.82) was estimated for julian day 65 (03/06/2011) (Fig. 4). In 2012, the LAI better adjusted to decreasing linear regression and the estimated decrease by angular coefficient was approximately 0.24 for each ten day delay in ST (Fig. 4). Decreasing linear and quadratic effects to plant height and LAI are in agreement with the results obtained by Vilhegas et al. (2001) and Marques et al. (2014), into work with ST of corn in the fall-winter in northwestern Paraná. The authors concluded that the reduction of temperature influence in reducing the vegetative growth of plants. Pronounced decreases in temperature proportional to the postponement of sowing were also observed in the climatic data of the present study (Fig. 1). Although the corn responds to interaction of various climatic factors, the greater influence on culture are solar radiation, rainfall and temperature (Brachtvogel et al., 2009). According to Verheul et al. (1996), the temperature is the main factor that controls the growth and development of corn. Reducing the temperature limits the photosynthetic process with reduced growth and the leaf area because there is less balance and consequently lower accumulation of photoassimilate in plant tissues, which limits the leaf expansion (Andrade et al., 1993). As well as verified for plant height (Table 3), the year 2012 overcame $2011 \quad(\mathrm{P} \leq 0.05)$, providing greater development of LAI in sweet corn plants at all times, on the average of hybrids (Table 4). These results permit the inference that the year 2012 provided more propitious climatic conditions for the growth and development of sweet corn plants, which can be easily observed in the topic Climate Characteristics. It is important to emphasize that in 2011 was founded tiniest temperatures, and even occurrence of frost (Fig. 1). This condition did not favor sweet corn culture because low temperatures induce reduction of metabolic activity of corn plants (Miedema, 1982), which reduces the values of the characteristics aerial parts of the plants (Verheul et al., 1996), as observed in plant height and LAI (Figs. 3 and 4). Additionally, it was found greater availability of radiation in 2012 in comparison with 2011 (Fig. 1). It is considered also that the smallest plant height and LAI observed in 2011 contributes as an aggravating because the interception of light by canopy is dependent of the height and leaf area (Marchão et al., 2006). 
Table 3. Plant height and yield of marketable ear of two sweet corn hybrids in two years in four sowing time (ST), in the fall-winter period in Maringá city, Northwest of Paraná State, Brazil.

\begin{tabular}{|c|c|c|c|c|c|c|c|c|}
\hline \multirow{2}{*}{ Factors } & $\mathrm{ST}_{1}$ & $\mathrm{ST}_{2}$ & $\mathrm{ST}_{3}$ & $\mathrm{ST}_{4}$ & $\mathrm{ST}_{1}$ & $\mathrm{ST}_{2}$ & $\mathrm{ST}_{3}$ & $\mathrm{ST}_{4}$ \\
\hline & \multicolumn{8}{|c|}{ Plant height (m) } \\
\hline Hybrids & \multicolumn{4}{|l|}{2011} & \multicolumn{4}{|l|}{2012} \\
\hline Tropical Plus & $1.52 \mathrm{a}^{*}$ & $1.75 \mathrm{a}$ & $1.65 \mathrm{a}$ & $1.39 \mathrm{a}$ & $2.16 \mathrm{a}$ & $2.00 \mathrm{~b}$ & $1.92 \mathrm{a}$ & $1.65 \mathrm{a}$ \\
\hline RB6324 & $1.54 \mathrm{a}$ & $1.71 \mathrm{a}$ & $1.65 \mathrm{a}$ & $1.43 \mathrm{a}$ & $2.16 \mathrm{a}$ & $2.11 \mathrm{a}$ & $1.98 \mathrm{a}$ & $1.68 \mathrm{a}$ \\
\hline Years & \multicolumn{4}{|c|}{ Tropical Plus } & \multicolumn{4}{|c|}{ RB6324 } \\
\hline 2011 & $1.52 \mathrm{~b}$ & $1.75 b$ & $1.65 b$ & $1.39 \mathrm{~b}$ & $1.54 \mathrm{~b}$ & $1.71 \mathrm{~b}$ & $1.65 \mathrm{~b}$ & $1.43 \mathrm{~b}$ \\
\hline 2012 & $2.16 \mathrm{a}$ & $2.00 \mathrm{a}$ & $1.92 \mathrm{a}$ & $1.65 \mathrm{a}$ & $2.16 \mathrm{a}$ & $2.11 \mathrm{a}$ & $1.98 \mathrm{a}$ & $1.68 \mathrm{a}$ \\
\hline & \multicolumn{8}{|c|}{ Yield of marketable ear $\left(\mathrm{Mg} \mathrm{ha}^{-1}\right)$} \\
\hline Hybrids & \multicolumn{4}{|l|}{2011} & \multicolumn{4}{|l|}{2012} \\
\hline Tropical Plus & $7.82 \mathrm{a}$ & $7.61 \mathrm{a}$ & $5.62 \mathrm{a}$ & $0.22 \mathrm{a}$ & $11.63 \mathrm{a}$ & $8.30 \mathrm{a}$ & $5.87 b$ & $1.66 \mathrm{~b}$ \\
\hline RB6324 & $8.05 \mathrm{a}$ & $7.80 \mathrm{a}$ & $4.89 \mathrm{a}$ & $0.28 \mathrm{a}$ & $11.91 \mathrm{a}$ & $8.62 \mathrm{a}$ & $7.80 \mathrm{a}$ & $2.44 \mathrm{a}$ \\
\hline Years & \multicolumn{4}{|c|}{ Tropical Plus } & \multicolumn{4}{|c|}{ RB6324 } \\
\hline 2011 & $7.82 \mathrm{~b}$ & $7.61 \mathrm{a}$ & $5.62 a$ & $0.22 \mathrm{~b}$ & $8.05 \mathrm{~b}$ & $7.80 \mathrm{~b}$ & $4.89 b$ & $0.28 \mathrm{~b}$ \\
\hline 2012 & $11.63 \mathrm{a}$ & $8.30 \mathrm{a}$ & $5.87 \mathrm{a}$ & $1.66 \mathrm{a}$ & $11.91 \mathrm{a}$ & $8.62 \mathrm{a}$ & $7.80 \mathrm{a}$ & $2.44 \mathrm{a}$ \\
\hline
\end{tabular}

$*$ Means followed by the same letter in the column do not differ significantly according to the by $\mathrm{F}$ test $(\mathrm{P} \leq 0.05)$. Sowing times $(\mathrm{ST}): \mathrm{ST}_{1}=02 / 18 ; \mathrm{ST}_{2}=03 / 04 ; \mathrm{ST}_{3}=$ $03 / 18$ and $\mathrm{ST}_{4}=04 / 01$.

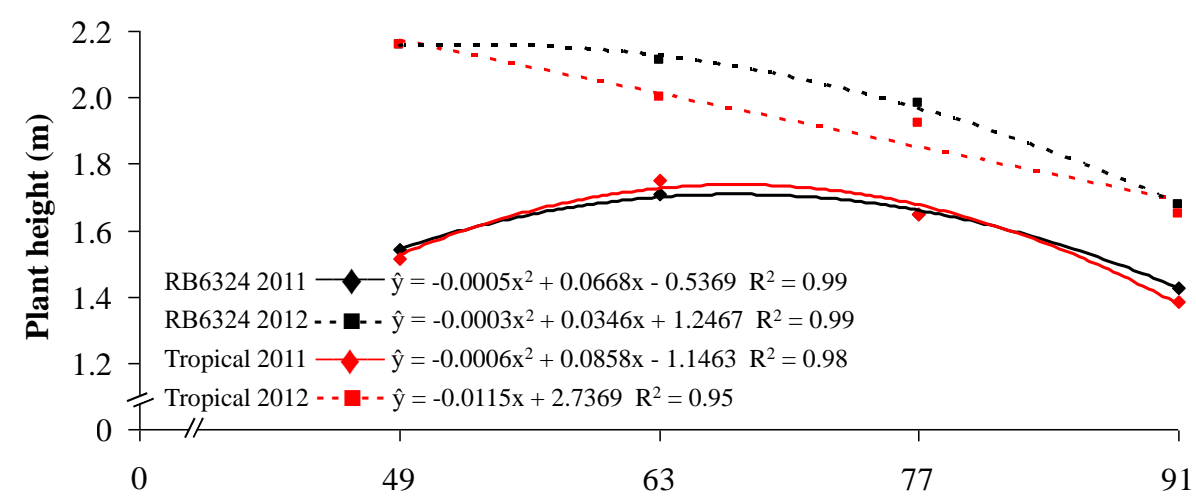

Julian day

Fig 3. Plant height of two sweet corn hybrids in relation to the sowing time (ST) in the fall-winter period of 2011 and 2012 , in Maringá, Northwest of Paraná State, Brazil.

$\mathrm{ST}_{1}=49(02 / 18) ; \mathrm{ST}_{2}=63(03 / 04) ; \mathrm{ST}_{3}=77(03 / 18)$ and $\mathrm{ST}_{4}=91(04 / 01)$.

Table 4. Leaf area index, number of kernel row per ear and number of kernel per row of two sweet corn hybrids in two years in four sowing time (ST), in the fall-winter period in Maringá city, Northwest of Paraná State, Brazil.

\begin{tabular}{|c|c|c|c|c|}
\hline \multirow{2}{*}{ Factors } & $\mathrm{ST}_{1}$ & $\mathrm{ST}_{2}$ & $\mathrm{ST}_{3}$ & $\mathrm{ST}_{4}$ \\
\hline & \multicolumn{4}{|c|}{ Leaf area index (average hybrids) } \\
\hline 2011 & $2.42 \mathrm{~b} *$ & $2.84 \mathrm{~b}$ & $2.57 \mathrm{~b}$ & $1.83 \mathrm{~b}$ \\
\hline \multirow[t]{2}{*}{2012} & $3.66 \mathrm{a}$ & $3.56 \mathrm{a}$ & $2.94 \mathrm{a}$ & $2.77 \mathrm{a}$ \\
\hline & \multicolumn{4}{|c|}{ Number of kernel row per ear (average years) } \\
\hline Tropical Plus & $15.80 \mathrm{a}$ & $15.65 \mathrm{a}$ & $15.38 \mathrm{a}$ & $14.10 \mathrm{~b}$ \\
\hline \multirow[t]{2}{*}{ RB6324 } & $15.58 \mathrm{a}$ & $15.83 \mathrm{a}$ & $15.10 \mathrm{a}$ & $14.98 \mathrm{a}$ \\
\hline & \multicolumn{4}{|c|}{ Number of kernel per row (average years ${ }^{(1)}$ and hybrids ${ }^{(2)}$ ) } \\
\hline${ }^{(1)}$ Tropical Plus & $38.30 \mathrm{a}$ & $40.50 \mathrm{a}$ & $33.85 \mathrm{a}$ & $21.23 \mathrm{~b}$ \\
\hline${ }^{(1)}$ RB6324 & $37.83 \mathrm{a}$ & $37.68 \mathrm{~b}$ & $33.70 \mathrm{a}$ & $24.24 \mathrm{a}$ \\
\hline (2) 2011 & $39.78 \mathrm{a}$ & $39.80 \mathrm{a}$ & $34.43 \mathrm{a}$ & $20.33 b$ \\
\hline${ }^{(2)} 2012$ & $36.35 \mathrm{~b}$ & $38.38 \mathrm{a}$ & $33.13 \mathrm{a}$ & $25.10 \mathrm{a}$ \\
\hline
\end{tabular}

*Means followed by the same letter in the column are not different by $\mathrm{F}$ test $(\mathrm{P} \leq 0.05)$. Sowing times $(\mathrm{ST}): \mathrm{ST}_{1}=02 / 18 ; \mathrm{ST}_{2}=03 / 04 ; \mathrm{ST}_{3}=03 / 18$ and $\mathrm{ST}_{4}=04 / 01$.

All these events contribute to lower dry matter accumulation in plants and, finally, to a lesser vegetative growth (Andrade et al., 1993; Tollenaar, 1999; Lindquist et al., 2005; Forsthofer et al., 2006). It is worth considering that there was no hydric restriction in both agricultural years, because the hydric deficit was isolated by supplementary irrigation.

\section{Production component characteristics}

The principal factors, times and years, tested isolated way for the characteristic number of kernel row per ear were significant (Table 2). However, the partitioning no significant interaction times $\mathrm{x}$ hybrids (Table 2) adjusted significantly $(\mathrm{P} \leq 0.05)$ and revealed more practical information than the principal factors (time and year). For these reasons, as well as the plant height (Fig. 3), was used the analysis relating to double interaction (times x hybrids) (Fig. 5), as suggested by Perecin and Cargnelutti Filho (2008) and Barbin (2013).

The number of kernel row per ear varied with the times and hybrid showing different performances in average years. The quadratic polynomial model and the decrease linear were that the best adjusted to the characteristic performance. The 


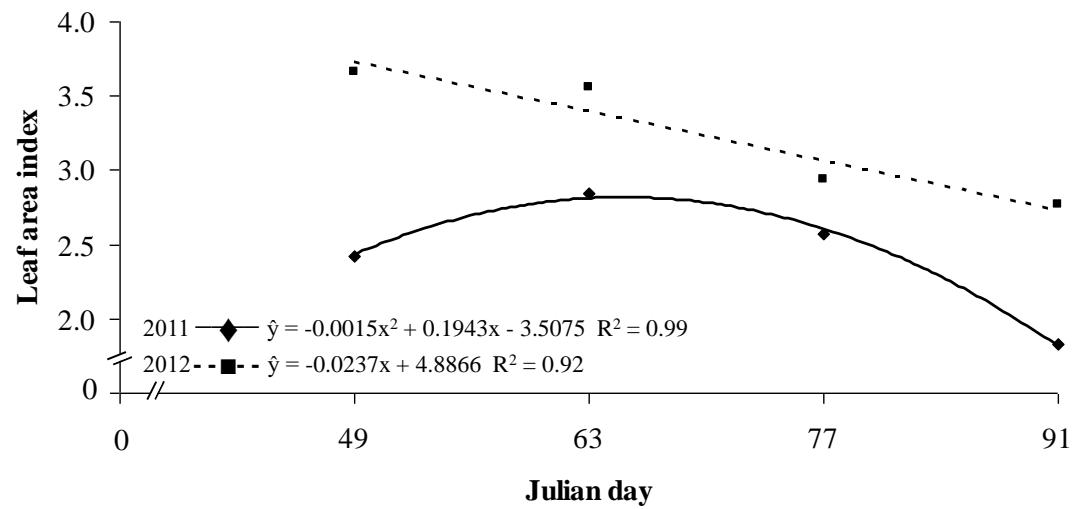

Fig 4. Average leaf area index of two sweet corn hybrids (Tropical Plus and RB6324) in relation to the sowing time (ST) in the fallwinter period of 2011 and 2012, in Maringá, Northwest of Paraná State, Brazil. ST $1=49$ (02/18); $\mathrm{ST}_{2}=63(03 / 04) ; \mathrm{ST}_{3}=77(03 / 18)$ and $\left.\mathrm{ST}_{4}=91(04 / 01) .18\right)$ and $\mathrm{ST}_{4}=91(04 / 01)$.

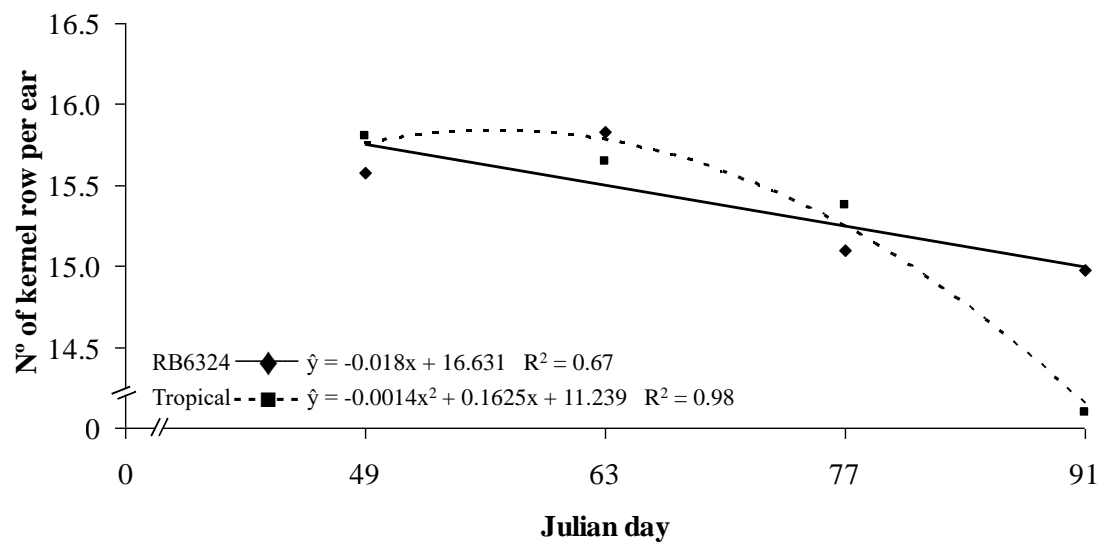

Fig 5. Number of kernel row per ear of two sweet corn hybrids in relation to the sowing time (ST) in the fall-winter period in average of the years 2011 and 2012, in Maringá, Northwest of Paraná State, Brazil.

$$
\left.\mathrm{ST}_{1}=49(02 / 18) ; \mathrm{ST}_{2}=63(03 / 04) ; \mathrm{ST}_{3}=77(03 / 18) \text { and } \mathrm{ST}_{4}=91(04 / 01) .18\right) \text { and } \mathrm{ST}_{4}=91(04 / 01)
$$

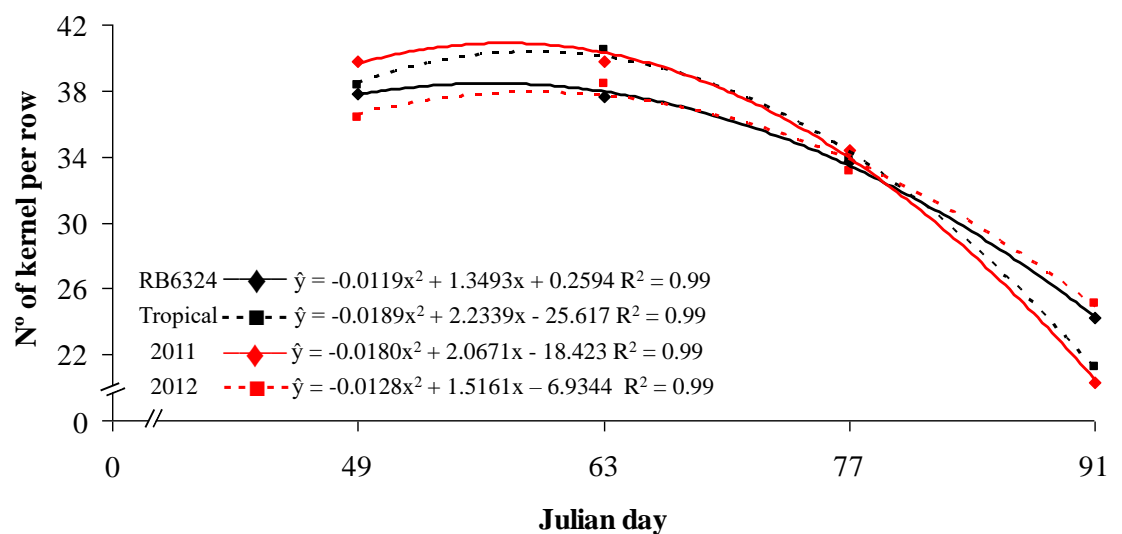

Fig 6. Number of kernel per row of two sweet corn hybrids (average years) in two years (average hybrids) in relation to the sowing time (ST) in the fall-winter period, in Maringá, Northwest of Paraná State, Brazil. 


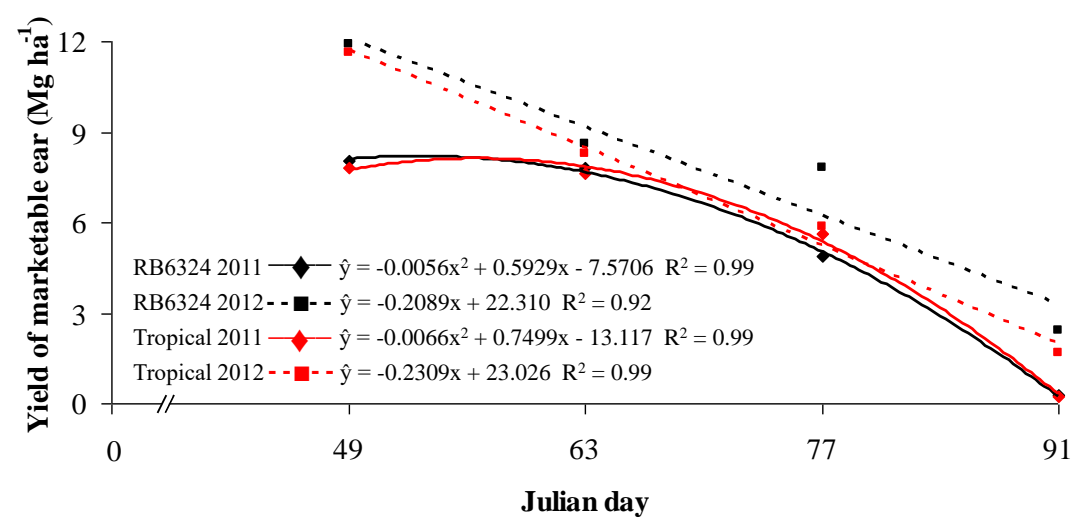

Fig 7. Yield of marketable ear of two sweet corn hybrids in relation to the sowing time (ST) in the fall-winter period of 2011 and 2012, in Maringá, Northwest of Paraná State, Brazil. ST $=49(02 / 18) ; \mathrm{ST}_{2}=63(03 / 04) ; \mathrm{ST}_{3}=77(03 / 18)$ and $\mathrm{ST}_{4}=91(04 / 01)$.

maximum number of kernel row per ear from hybrid Tropical Plus (16) was estimated for the julian day 57 (02/26). For the linear model (RB6324) the decrease estimated by the angular coefficient, was 1.8 rows to one hundred days of delay in ST (Fig. 5). The characteristic number of kernel per row was significant $(\mathrm{P} \leq 0.05)$ for interactions times $\mathrm{x}$ hybrids and times $\mathrm{x}$ years (Table 2). Hybrids and years had similar performances and the quadratic polynomial model had the best adjustment. The maximum numbers of kernels per row were $38.4 ; 40.4 ; 40.9$ and 37.9 in sowing estimated for the julian days 57 (02/26), 59 (02/28), 57 (02/26/2011) and 59 (02/28/2012), respectively for hybrids RB6324 and Tropical Plus (average years); and the years 2011 and 2012 (average hybrids) (Fig. 6). The estimate of the julian day for the maximum number of kernel per row $(58=02 / 27-$ Fig. 6$)$ and the number of kernel rows per ear $(57=02 / 26-$ Fig. 5$)$ are very close to those estimated for the growth characteristics (62 - plant height and 65 - LAI, Figs. 3 and 4), and after these dates, significant reductions were found for all the production components. Nevertheless, the reduction in vegetative growth on plants sown in March (Figs. 3 and 4) probably limited source of photosynthetic (Tollenaar, 1999) which resulted in lower values of yield components (Figs. 5 and 6). Leaf area is often correlated with corn production, once the leaves of the plants have a fundamental role in the uptake and conversion of solar radiation to chemical energy in the photosynthetic process (Andrade et al., 1993; Duete et al., 2008; Tsimba et al., 2013a). The partitioning of the triple interaction (times $\mathrm{x}$ hybrids $\mathrm{x}$ years) for yield of marketable ear showed different performances, adjusting the quadratic and decreasing linear models in 2011 and 2012 respectively (Fig. 7). In 2011 the maximum yields obtained by the RB6324 and Tropical Plus hybrids were 8.2 and $8.1 \mathrm{Mg}^{-}$ ${ }^{1}$,estimated for the julian days $53(2 / 22 / 2011)$ and 57 $(2 / 26 / 2011)$, respectively. On the other hand, in 2012, the decrease estimated by the angular coefficients in the sweet corn productivity were $208.9 \mathrm{~kg}$ (RB6324) and $230.9 \mathrm{~kg}$ (Tropical Plus) for each day of delay in ST (Fig. 7).

Taking as a basis the average price $\mathrm{kg}^{-1}$ of sweet corn ears in Brazil (U\$ $0.73=\mathrm{R} \$ 2.2$ ) in July/2015 it is imperative to say that, in the agricultural year 2012, for each day of delay in the ST of crop, the loss was U\$ 153 day ha ${ }^{-1}$ (RB6324) and R\$ 169 day ha $^{-1}$ (Tropical Plus) per hectare. Then, the sweet corn cultivation constitutes a rewarding source of income due to the high price of the ears (Caniato et al., 2007). So beyond appealing, the economic return is relatively fast, because it is harvested green, becoming an excellent alternative for family farming (Khan et al., 2011). However, much of the farmer's profit can be lost with sowings in inappropriate times in the
Northwest Region of Paraná State. In 2012, the trend observed was that higher yields could be obtained with earlier sowing the first tested (Fig. 7). The same applies to plant height (Fig. 3), LAI (Fig. 4) and the number of kernel row per ear (Fig. 5). That is, the characteristics studied, suffered sharp reductions with the delay of ST, with pronounced negative effects, especially on productivity (Fig. 7). Other studies have found that the delay in ST negatively influenced the sweet corn production (Martin and Williams, 2008; Khan et al., 2011). These results can be explained by the fact that weather conditions, particularly low temperatures were more restrictive with delay of sowing (Fig. 1). Under adverse weather conditions (mainly temperature), the plants receive more sunlight than they can use in the transport of electrons during photosynthesis and fixation of $\mathrm{CO}_{2}$ (Verheul et al., 1996). These cause a photooxidative damage with the consequent activation of molecular $\mathrm{O}_{2}$ in reactive oxygen species (ROS) (Gill and Tuteja, 2010). ROS are responsible for lipid peroxidation (Müller et al., 2001). Additionally ROS induce loss of structural and functional integrity of cell membranes, decrease of the activity of various enzymes and inhibition of nutrient acquisition capacity. Moreover, ROS are highly toxic to the vital constituent of cell and one of the responsible for the destruction of chlorophyll, DNA, lipids and membrane proteins (Zhu, 2001; Gill and Tuteja, 2010). For these reasons, the photooxidative damage is the key process involved in cell damage and death of plant cells exposed to environmental stress factors (Foyer et al., 1994). Low temperatures have an important role in the formation of ROS (Ortiz-Lopez et al., 1990) by the NADPH oxidase (Shen et al., 2000) and due to impairment of electron transport during photosynthesis (Foyer et al., 1994).

On cultural level, the consequence of the low temperatures is reduction in radiation use efficiency (RUE), production of biomass per unit of light intercepted by the canopy (Verheul et al., 1996; Edreira and Otegui, 2012), as reported for corn (Cicchino et al., 2010; Tsimba et al., 2013a). RUE decreased with decreasing temperature of 21 to $16^{\circ} \mathrm{C}$ (Andrade et al., 1993). In corn grown in regions characterized by a cold spring $\left(15\right.$ to $\left.18^{\circ} \mathrm{C}\right)$ the RUE was lower than for corn grown in warmer regions (Andrade et al., 1993). Part of this inefficiency could be due to photoinhibition, (Ortiz-Lopez et al., 1990) and these climatic conditions were observed during the conduct of this study (Fig. 1). In Table 3, it can be seen that the studied hybrids showed statistical performances similar $(P \geq 0.05)$ to the characteristic yield of marketable ear at all times in 2011. However, although during all the plant development cycle, in both years, experiments have been 
irrigated, there were statistical differences between the years crops (Table 3). The year 2012 overcame $2011(\mathrm{P} \leq 0.05)$ in almost all times for both hybrids (Table 3 ).

Martin and Williams (2008) investigating the effect of ST on the sweet corn crop with supplemental irrigation, have found that yield was higher in 2007 than in 2006. The authors concluded that yield differences were consistent with total biomass of the aerial part and differences LAI observed in both years.

Among the factors already discussed, the low yield of marketable ear in the first year, compared to 2012 can be justified by the greater availability of solar radiation in 2012 (Fig. 1). Solar radiation is one of the most influential climatic factors on the corn crop because they act directly on the physiological activities, interfering on the production (Brachtvogel et al., 2009). Although not evaluated, strong evidence indicates that the RUE was preponderant to justify the superiority of the year 2012 because the year 2011 was cooler (Fig. 1), which as well documented, decreases the RUE. However, probably, in 2011, beyond the radiation had been used inefficiently, it was naturally limited (Fig. 1).

Additionally, these climatic conditions resulted in less developed plants, represented by low values plant height of 1.58 (2011) against 1.96 (2012) (Table 3) and LAI 2.42 (2011) versus 3.23 (2012) (Table 4). Thus, the plants showed a smaller canopy in the agricultural year 2011 able to potentiate the interception of solar radiation (Sangoi, 2001; Marchão et al., 2006), which is one of the main determinants of productivity (Tsimba et al., 2013a). This observation leads to lower accumulation of nutrients, lower production of photoassimilates and finally lower translocation of these photoassimilates for grain filling, providing reductions in yield potential (Duete et al., 2008).

Another relevant results in Table 3 is the superiority of RB6324 hybrid $(\mathrm{P} \leq 0.05)$ in the last two ST $(03 / 18$ and $04 / 01)$ in the agricultural year of 2012 as well as last time for number of kernel row per ear and number of kernel per row (Table 4). The latter two ST, independent of the years were those that provided worst weather conditions (Fig. 1). However, by exploitation characteristics of sweet corn, it is common escalated sowing during the whole year (Teixeira et al., 2001), or at least in part of the year (Martin and Williams, 2008), being almost inevitable no coincidence cycle with adverse climatic factors (Teixeira et al., 2001; Martin and Williams, 2008). In that situation, hybrid more productive under restrictive weather conditions comes up as a valuable tool.

Okumura et al. (2014) also noted superiority of hybrid RB6324 compared to Tropical Plus for the characteristic of yield of marketable ear. The authors emphasized the importance of this discovery for sweet corn producers, once they are remunerated by the quantity and quality of produced green ears.

\section{Materials and Methods}

\section{Study site}

The experiments were carried out in the fall-winter period of 2011 and 2012 agricultural years, in Maringá, Northwestern Paraná State, Brazil (geographic coordinates: 2320'48” S and $52^{\circ} 04^{\prime} 17^{\prime}$ ' $\mathrm{W}$, approximate altitude of $550 \mathrm{~m}$ ).

The climate of Northwestern Paraná, according to the Köppen classification, is the Cfa type, defined as a Subtropical climate, with average temperature in the coldest month lower than $18{ }^{\circ} \mathrm{C}$ (mesothermic), and the average temperature in the warmest month over $22^{\circ} \mathrm{C}$. The summers are warm, frosts are infrequent and rainfall tends to concentrate in summer period, but without a specific dry season. Data of temperature, solar radiation, photoperiod, rainfall and supplementary irrigation that occurred during each one of the agricultural years are presented in Fig. 1. Data from maximum, average and minimum temperatures were used to determine the thermal amplitude (Fig. 1) and accumulated thermal sum.

The accumulated thermal sum by sweet corn plants was determined by the thermal sum daily units, according to Cross and Zuber (1972), using the modified expression:

$$
A T S=\sum_{n=1}^{N} T S\left(\frac{T_{\max }+T_{\min }}{2}\right)-T_{b}
$$

where: ATS $=$ accumulated thermal sum $\left({ }^{\circ} \mathrm{C}\right.$ day $\left.^{-1}\right) ; \Sigma \mathrm{TS}=$ thermal sum daily $\left({ }^{\circ} \mathrm{C}\right.$ day $\left.^{-1}\right) ; \mathrm{N}=$ number of days; $\mathrm{Tmax}=$ maximum air temperature $\left({ }^{\circ} \mathrm{C}\right)$; Tmin $=$ minimum air temperature $\left({ }^{\circ} \mathrm{C}\right) ; \mathrm{Tb}=$ base air temperature of the corn crop, for which $10^{\circ} \mathrm{C}$ was adopted (Monteith and Elston, 1993).

The soil from experimental area was classified as dystroferric Red Nitissol (Embrapa, 2013), clayey texture (clay: $520 \mathrm{~g} \mathrm{~kg}$ ${ }^{1}$; silt: $140 \mathrm{~g} \mathrm{~kg}^{-1}$; sand: $340 \mathrm{~g} \mathrm{~kg}^{-1}$ ) and the results of the chemical analyses of the main characteristics of soil material from 0.0 to $0.20 \mathrm{~m}$ and 0.20 to $0.40 \mathrm{~m}$ layers are shown in Table 1 .

\section{Treatments, experimental design and plot}

The experiments was conducted in randomized complete block design, in a factorial $4 \times 2$ with four replications in two agricultural years (2011 and 2012). The factors studied were: i) Factor $\mathrm{A}$ - four $\mathrm{ST}\left(\mathrm{ST}_{1}-02 / 18 ; \mathrm{ST}_{2}-03 / 04 ; \mathrm{ST}_{3}-03 / 18\right.$; and $\mathrm{ST}_{4}-04 / 01$ ) and ii) Factor B - two sweet corn simple hybrids (Tropical Plus and RB6324). Each experimental plot was constituted of five rows of plants with $6.0 \mathrm{~m}$ in length, spaced by $0.9 \mathrm{~m}$ (Marques et al., 2015), totaling a total area of $27 \mathrm{~m}^{2}$ and an experimental area of $13.5 \mathrm{~m}^{2}$.

\section{Crop management}

The sowing density used was 5 plants $\mathrm{m}^{-1}$ in no-tillage system in order to reach a population density of approximately 55.500 plants ha $^{-1}$ (Souza et al., 2013). Management of fertilizing was according to Okumura et al. (2014) and all other cultivation techniques used were those recommended for the corn crop, including irrigation management (Embrapa, 2012).

\section{Evaluated characteristics}

The phytotechnical evaluations of growth (plant height and LAI) were assessed in five randomly selected plants in each plot at $\mathrm{V}_{\mathrm{T}}$ (Ritchie et al., 1993). Plant height was measured on the stem length from the soil surface to the base of the male inflorescence (Lana et al., 2009). The LAI was obtained by measuring the length $(\mathrm{L})$ and the width $(\mathrm{W})$ of all the leaves in each plant. Adopting the proposal by Francis et al. (1969), the leaf area (LA) was calculated by the following equation: $\mathrm{LA}=0.75 \times \mathrm{L} \times \mathrm{W}$. Later, the LAI was calculated from the LA measures by the equation: $L A I=\frac{L A}{\left(S_{1} * S_{2}\right)}$, where $\mathrm{s}_{1}$ and $\mathrm{s}_{2}$ refer to the spacing in meter $(\mathrm{m})$ between plants and between rows, respectively.

The sweet corn ears were harvested at $\mathrm{R}_{3}$ (Ritchie et al., 1993). On this occasion was assessed the yield of dehusked marketable ear (length greater than $15 \mathrm{~cm}$, diameter greater than $3 \mathrm{~cm}$ and free from pests, according to Albuquerque et al. 2008). After that, five ears were obtained randomly from 
each experimental plot to measure the number of kernel per row, and the number of kernel row per ear (Vieira et al., 2010).

\section{Data analysis}

The experimental data from each one of the agricultural years were assessed using the Shapiro-Wilks and Levene tests $(\mathrm{P} \leq 0.01)$ to verify the normality and homoscedasticity waste. Later, the data were subjected to an individual analysis of variance, and was verified whether the relationships between the residual mean squares were lower than 7:1 (Banzatto and Kronka, 2006). Finally, the data were submitted to analysis of variance, and then partitioning as necessary (Perecin and Cargnelutti Filho, 2008; Barbin, 2013).

The ST effects were studied by polynomial regression analysis and the effects of the hybrids and years were studied by the $\mathrm{F}$ test $(\mathrm{P} \leq 0.05)$ of the analysis of variance. All these statistical procedures were carried out by the Sisvar Computer Program (Ferreira, 2011).

\section{Conclusions}

The sweet corn plant growth was limited by delay in the sowing time that negatively affected the production components. The hybrid RB6324 showed better productive performance when climatic conditions were more limiting. The delay in sowing times did not provide variation in accumulation thermal sum among sowing times. The thermal sum accumulation between sowing - tasseling and between tasseling - milky grains were 848 and 272 , respectively. The delay in sowing increased the vegetative and reproductive phases of the RB6324 and Tropical Plus hybrids. The number of days between sowing - tasseling and between tasseling milky grains were 61 and 32 days, respectively, for the first sowing time (02/18) and 82 and 38 for the last sowing time $(04 / 01)$. The second half of the February was a better time for sowing sweet corn in the fall-winter period in the Northwest Region of Paraná State, Brazil.

\section{Acknowledgements}

We thank the Conselho Nacional de Pesquisa (CNPq/Brazil) for Productivity in Research Scholarship and Fundação Araucária by financial support for this research work. We also appreciate the scholarship from Coordenação de Aperfeiçoamento de Pessoal de Nível Superior (CAPES/Brazil).

\section{References}

Albuquerque CJB, Von Pinho RG, Borges ID, Souza Filho AX, Fiorini IVA (2008) Performance of experimental and commercial hybrids of maize for the production of green maize. Cienc Agrotec. 32:768-775.

Andrade FH, Uhart SA, Cirilo A (1993) Temperature affects radiation use efficiency in maize. Field Crops Res. 32:1725.

Aroca R, Porcel R, Ruíz-Lozano JM (2012) Regulation of root water uptake under abiotic stress conditions. J Exp Bot. 63:43-57.

Banzatto DA, Kronka SN (2006) Experimentação agrícola. $4^{\text {th }}$ edn. FUNEP, Jaboticabal. 237p.

Barbieri VHB, Luz JMQ, Brito CH, Duarte JM, Gomes LS, Santana DG (2005) Sweet corn hybrids productivity and industrial yield as a function of spacing and plant population. Hort Bras. 23:826-830.
Barbin D (2013) Planejamento e análise estatística de experimentos agronômicos. $2^{\text {th }}$ edn. Macenas, Porto Alegre. $214 \mathrm{p}$.

Bergamaschi H, Dalmago GA, Comiran F, Bergonci JI, Müller AG, França S, Santos AO, Radin B, Bianchi CAM, Pereira PG (2006) Water deficit and yield in maize crop. Pesq Agropec Bras. 41:243-249.

Borrás L, Westgate ME, Astini JP, Echarte L (2007) Coupling time to silking with plant growth rate in maize. Field Crops Res. 102:73-85.

Boyer CD, Shannon JC (1984) The use of endosperm genes for sweet corn improvement. Plant Breed Rev. 1:139.

Brachtvogel EL, Pereira FRS, Cruz SCS, Bicudo SJ (2009) Maize plant densities in conventional and equidistant plant spacing. Cienc Rural. 39:2334-2339.

Caniato FF, Galvão JCC, Finger FL, Puiatti M, Oliveira DA, Ferreira JL (2007) Quantification of total soluble sugars, reducing sugars and starch in immature kernels of corn cultivars. Cienc Agrotec. 31:1893-1896.

Cicchino M, Edreira JIR, Uribelarrea M, Otegui ME (2010) Heat stress in field grown maize: response of physiological determinants of grain yield. Crop Sci. 50:1438-1448.

Costa EFN, Souza JC, Lima JL, Cardoso GA (2010) Genotype by environment interaction in different types of maize hybrids. Pesq Agropec Bras. 45:1433-1440.

Creech RG (1965) Genetic control of carbohydrate synthesis in maize endosperm. Genetics. 52:1175-1185.

Cross HZ, Zuber MS (1972) Prediction of flowering dates in maize based on different methods of estimating thermal units. Agron J. 64:351-355.

Cruz JC, Silva GH, Pereira Filho IA, Gontijo Neto MMS, Magalhães PC (2010) Characterization of off-season maize cropping system of high productivity in 2008 and 2009. Rev Bras Milho Sorgo. 9:177-188.

Duete RRC, Muraoka T, Silva EC, Trivelin PCO, Ambrosano EJ (2008) Nitrogen fertilization management and nitrogen $\left({ }^{15} \mathrm{~N}\right)$ utilization by corn crop in Red Latosol. Rev Bras Cienc Solo. 32:161-171.

Echarte L, Andrade FH, Vega CRC, Tollenaar M (2004) Kernel number determination in Argentinean maize hybrids released between 1965 and 1993. Crop Sci. 44:1654-1661.

Edreira JIR, Otegui ME (2012) Heat stress in temperate and tropical maize hybrids: differences in crop growth, biomass partitioning and reserves use. Field Crops Res. 130:87-98.

Embrapa - Empresa Brasileira de Pesquisa Agropecuária, Centro Nacional de Pesquisa de Milho e Sorgo (2012) Cultivo do milho. $8^{\text {th }}$ edn. Versão eletrônica, EmbrapaCNPMS. Accessed on June 10, 2013. Available in: $<$ http://www.cnpms.embrapa.br/publicacoes/milho_8_ed/in dex.htm>.

Embrapa - Empresa Brasileira de Pesquisa Agropecuária (2013) Sistema brasileiro de classificação de solos. $3^{\text {th }}$ edn. Embrapa, Brasília. 353p.

Ferreira DF (2011) Sisvar: a computer statistical analysis system. Cienc Agrotec. 35:1039-1042.

Folberth C, Gaiser T, Abbaspour KC, Schulin R, Yang H (2012) Regionalization of a large-scale crop growth model for sub-Saharan Africa: model setup, evaluation, and estimation of maize yields. Agric Ecosyst Environ. 151:2133.

Forsthofer EL, Silva PRF, Strieder ML, Minetto T, Rambo L, Argenta G, Sangoi L, Suhre E, Silva AA (2006) Agronomic yield and economic performance of maize in different management levels and sowing times. Pesq Agropec Bras. 41:399-407.

Foyer CH, Lelandais M, Kunert KJ (1994) Photooxidase stress in plants. Physiol Plant. 92:696-717. 
Francis CA, Rutger JN, Palmer AFEA (1969) Rapid method for plant leaf area estimation in maize (Zea mays). Crop Sci. 9:537-539.

Gaile Z (2012) Maize (Zea mays L.) response to sowing timing under agro-climatic conditions of Latvia. Zemd Agricu. 99:31-40.

Gill SS, Tuteja N (2010) Reactive oxygen species and antioxidant machinery in abiotic stress tolerance in crop plants. Plant Physiol Biochem. 48:909-930.

Guei RG, Wasson CE (1992) Inheritance of some drought adaptative trait in maize. I. Interrelationships between yield, flowering and ears per plant. Maydica. 37:157-164.

Guy C (1990) Cold acclimation and freezing stress tolerance: role of protein metabolism. Annu Rev Plant Physiol Plant Mol. 41:187-223.

IPCC - Intergovernmental Panel on Climate Change (2013) Climate Change 2013: the physical science basis. In: Stocker T, Dahe Q, Plattner G (eds) (2013) Working group I contribution to the IPCC fifth assessment report. Stockholm, Sweden. 2216p.

Khan ZH, Khalil SK, Farhatullah, Khan MY, Israr M, Basir A (2011) Selecting optimum planting date for sweet corn in Peshawar, Pakistan. Sarhad J Agric. 27:341-347.

Lana MC, Woytichoski Jr PP, Braccini AL, Scapim CA, Ávila MR, Albrecht LP (2009) Spacing and top-dressing with nitrogen in corn culture. Acta Sci Agron. 31:433-438.

Larcher W (2000) A planta sobre estresse. In: Larcher W (ed) Ecofisiologia vegetal. Rima Artes e Textos, São Carlos. p 341-437.

Laux P, Jackel G, Tingem RM, Kunstmann H (2010) Impact of climate change on agricultural productivity under rainfed conditions in Cameroon. A method to improve attainable crop yields by planting date adaptations. Agric For Meteorol. 150:1258-1271.

Lindquist JL, Arkebauer TJ, Walters DT, Cassman KG, Dobermann A (2005) Maize radiation use efficiency under optimal growth conditions. Agron J. 97:72-78.

Liu Z, Hubbard KG, Lin X, Yang X (2013) Negative effects of climate warming on maize yield are reversed by the changing of sowing date and cultivar selection in Northeast China. Glob Change Biol. 19:3481-3492.

Liu Z, Yang X, Hubbard KG, Lin X (2012) Maize potential yields and yield gaps in the changing climate of northeast China. Glob Change Biol. 18:3441-3454.

Marchão RL, Brasil EM, Ximenes PA (2006) Interceptation of photossintetic active radiation and grain yield of maize under high plant density. Rev Bras Milho Sorgo. 5:170181.

Marques OJ, Vidigal Filho PS, Scapim CA, Franco AAN, Okumura RS, Reche DL, Numoto AY (2014) Sowing time of popcorn under supplementary irrigation in the second season in Parana State, Brazil. J Food Agric Environ. 12:640-647.

Marques OJ, Vidigal Filho PS, Scapim CA, Bonato CM, Okumura RS, Silva LI, Souza RS (2015) Sowing time of popcorn during the summer harvest under supplemental irrigation in Ferralic Nitisol and subtropical climate. Aust J Crop Sci. 9:413-423.

Martin M, Williams II (2008) Sweet corn growth and yield responses to planting dates of the North Central United States. HortSci. 43:1775-1779.

Miedema P (1982) The effects of low temperature on Zea mays. Adv Agron. 35:93-128.

Monteith JL, Elston J (1993) Climatic constraints on crop production, In: Fowden L, Mansfield T, Stoddart J (ed) Plant adaptation to environmental stress. Chapman e Hall, London. p 3-18.
Müller P, Li XP, Niyogi KK (2001) Non-photochemical quenching. A response to excess light energy. Plant Physiol. 125:1558-1566.

Okumura RS, Vidigal Filho OS, Scapim CA, Marques OJ, Franco AAN, Souza RS, Reche DL (2014) Effects of nitrogen rates and timing of nitrogen topdressing applications on the nutritional and agronomic traits of sweet corn. J Food Agric Environ. 12:391-398.

Ortiz-Lopez A, Ying Nie G, Oft DR, Baker NR (1990) The involvement of the photoinhibition of photosystem II and impaired membrane energization in the reduced quantum yield of carbon assimilation in chilled maize. Planta. 181:78-84.

Pagano E, Maddonni GA (2007) Intra-specific competition in maize: early established hierarchies differ in plant growth and biomass partitioning to the ear around flowering. Field Crops Res. 101:306-320.

Perecin D, Cargnelutti Filho A (2008) Efeitos por comparações e por experimento em interações de experimentos fatoriais. Cienc Agrotec. 32:68-72.

Resende M, Oliveira AC (2005) Comparison of different irrigation scheduling strategies on maize. Rev Bras Milho Sorgo. 4:205-214.

Ritchie SW, Hanway JJ, Benson GO (1993) How a corn plant develops. Special Report n.48. Iowa State University of Science and Technology, Ames. Cooperative Extension Service.

Sangoi L (2001) Understanding plant density effects on maize growth and development: an important issue to maximize grain yield. Cienc Rural. 31:159-168.

Sangoi L, Schmit A, Zanin CG (2007) Leaf area and grain yield of maize hybrids at different plant populations. Rev Bras Milho Sorgo. 6:263-271.

Sangoi L, Silva PRF, Silva AA, Ernani PR, Horn D, Strieder ML, Schmitt A, Schweitzer C (2006) Agronomic performance of maize cultivars at four management systems. Rev Bras Milho Sorgo. 5:218-231.

Shen W, Nada K, Tachibana S (2000) Involvement of polyamines in the chilling tolerance of cucumber cultivars. Plant Physiol. 124:431-439.

Silva MAV, Ferreira WPM, Andrade VMS, Araujo SGA (2010) Corn sowing time in Sete Lagoas region, Minas Gerais State, based on the probability of occurrence of dry and rainy spells. Rev Ceres. 57:454-458.

Soler CMT, Sentelhas PC, Hoogenboom G (2005) Thermal time for phenological development of four maize hybrids grown off-season in a subtropical environment. J Agric Sci. 143:169-182.

Souza RS, Vidigal Filho OS, Scapim CA, Marques OJ, Queiroz DC, Okumura RS, Reche DL, Cortinove VB (2013) Yield and quality of sweet corn at different plant populations. Semina: Ciências Agrárias. 34:995-1010.

Steudle E (2000) Water uptake by roots: effects of water deficit. J Exp Botan. 51:1531-1542.

Streck NA, Silva SD, Langner JA (2012) Assessing the response of maize phenology under elevated temperature scenarios. Rev Bras Meteorol. 27:1-12.

Teixeira FF, Sousa IRP, Gama EEG, Pacheco CAP, Parentoni SN, Santos MX, Meirelles WF (2001) Combine ability of sweet corn inbredlines. Cienc Agrotec. 25:483488.

Tollenaar M (1999) Duration of the grain-filling period in maize is not affected by photoperiod and incident PPFD during the vegetative phase. Field Crops Res. 62:15-21. 
Tsimba R, Edmeades GO, Millner JP, Kemp PD (2013b) The effect of planting date on maize: phenology, thermal time durations and growth rates in a cool temperate climate. Field Crops Res. 150:145-155.

Tsimba R, Edmeades GO, Millner JP, Kemp PD (2013a) The effect of planting date on maize grain yields and yield componentes. Field Crops Res. 150:135-144.

Verheul MJ, Picatto C, Stamp P (1996) Growth and development of maize (Zea mays L.) seedlings under chilling conditions in the field. Europ J Agron. 5:31-43.

Vieira MA, Camargo MK, Daros E, Zagonel J, Koehler HS (2010) Maize cultivars and plant population affecting green ear yield. Acta Sci Agron. 32:81-86.

Vilhegas ACG, Vidigal Filho PS, Scapim CA, Gonçalves Vidigal MC, Braccini AL, Sagrilo E (2001) Effect of sowing times and yield stability of corn hybrids cultivated during the autumn-winter period in the Northwest of Paraná State. Bragantia. 60:45-51.
Waha K, Müller C, Bondeau A, Dietrich JP, Kurukulasuriya P, Heinke J, Lotze-Campen H (2013a) Adaptation to climate change through the choice of cropping system and sowing date in sub-Saharan Africa. Glob Environ Change. 23:130-143.

Waha K, Müller C, Rolinski S (2013b) Separate and combined effects of temperature and precipitation change on maize yields in sub-Saharan Africa for mid- to late-21st century. Glob Plan Change. 106:1-12.

Zhu JK (2001) Plant salt tolerance. Trends Plant Sci. 6:66-71. Zinselmeier C, Westgate ME, Jones RJ (1995) Kernel set at low water potential does not very with source/sink ratio in maize. Crop Sci. 35:158-163. 